\title{
RETHINKING THE PHILOSOPHY OF HISTORY'S PARADIGM IN STUDYING CIVILIZATION: AN ANALYSIS OF MALEK BENNABI'S CRITICAL REVIEW
}

\author{
Badrane Benlahcene \\ Islamic Studies, Program of Comparative Religions, \\ Hamad Bin Khalifa University, Doha
}

\begin{abstract}
This paper analyzes the philosophy of history's paradigm in studying civilization. It critically reviews the approaches of the progressive school, within this paradigm, developed by the late Algerian thinker and philosopher of civilization' Malek Bennabi (1905-1973). It discusses the concept of the evolution of the civilization formulated by the pioneers of this paradigm and their main ideas concerning civilization and its course in the history. It tries to find out what Bennabi mainly criticizes and considers the shortcomings of the progressive school, in the philosophy of history, concerning the study of civilization. Bennabi was of the view that this school's approaches are more theoretical than historical, it is based on Euro-centric worldviews which sees the history of modern Europe as the culmination of the progress of human history without any critical analysis of the various civilized experiences. Therefore, this approach focus on some variables of a historical change while neglecting the complexity of a civilization as a multivariate phenomenon. Although Bennabi acknowledged the care of the Hegelians about the role of ideas in changing the history, and the Marxists' praise of dialectical analysis, he was of the view that this school was not related to the nature of civilization. Consequently, he criticized this school in terms of the limitations of method, concepts, and perspectives.
\end{abstract}

Keywords: philosophy of history, progressive school, Hegel, Marx, Comte, Bennabi, civilization

\section{Introduction}

Throughout history, the study of civilization attracted many researchers and fields of research. Therefore, the causes, emergence, rise, interactions, achievements, decline and fall of civilizations have been explored at length by distinguished historians, sociologists, anthropologists, philosophers, and other people who were concerned with civilization.

Although, there is a broad agreement on central propositions concerning the nature, identity, and dynamics of civilizations, there exist differences in perspective, methodology, focus, and concepts which envelop various approaches.

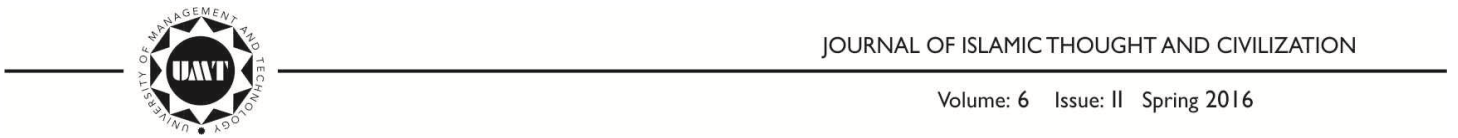


In this context, this paper attempts to analyze the paradigm of philosophy of history with its various perspectives and schools which for a long time had been the leading paradigm of civilization studies. Furthermore, this paper tries to analyze Malek Bennabi's critical review of the contributions of the mentioned paradigm.

\section{The Approach of the Philosophy of History}

The philosophy of history was born out of the human endeavor to give rational explanations of events. Besides, it is an attempt to discover the law that regulates them and to trace a meaning in its operation that introduces logical order into events of the past, illuminates the present and casts some light upon the future. ${ }^{1}$ In other words, while history is a "first order" study of past actions, events and situations, the philosophy of history is a "second order" study. It is the analysis of the study of these topics. It can be considered as a "meta" study, which means it does not deal, directly, with the events, actions and situations; rather it is an indirect study seeking to explain and elaborate answers to those happenings of the past. Therefore, philosophers of history, typically, aim to arrive at comprehensive views of the process of history as a whole. They view themselves as synthesizing or generalizing in a grand manner on the basis of detailed data supplied by more workaday historians. ${ }^{2}$

Although, there is an academic distinction between the subject matter of the historians and that of the philosophers of history, it is difficult to find a historian who does not have a sort of philosophy about his historical writings. Thus, there is no sharp border between the subject matter of the two disciplines. That is to say, it is difficult to treat history without taking into consideration some philosophical questions regarding the causes of events, the course of history, the process of change, and the forces behind the movement of history.

Historians seek to describe not only what happened in the past but also why society changes. Any research of this kind raises a number of fundamental questions. First question is regarding the actors of history in terms of the role of providence, the individual and the group in history. Second question is the presence of universal patterns in historical movement; that is, the extents to which historical events are unique or fit into patterns. Third question is; whether there is progress in human affairs or not. Also, is there a cyclical movement of ups and downs or not? These are the general questions that this paradigm raises, while studying history.

${ }^{1}$ R. G. Collingwood The Idea of History (Oxford: Oxford University Press, 1993), 1-3; Paul Edwards, (Editor in Chief), Encyclopedia of Philosophy (New York: Macmillan Publishing Co, 1967), 6/247; Abdul Hameed Siddiqui, A Philosophical Interpretation of History (Lahore: Kazi Publications, 1979), 2.

${ }^{2}$ R. F. Atkinson, Knowledge and Explanation in History: An Introduction to the Philosophy of History (Ithaca: Cornell University Press, 1978), 7-8; Collingwood, The Idea of History, 1.

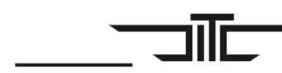

JOURNAL OF ISLAMIC THOUGHT AND CIVILIZATION 
The answers to these questions vary with different philosophical views of mankind, and thus give rise to many schools of thought which in turn may vary in their approaches.

Regarding the question of the actors in history, there are many schools and views on this issue. Some schools emphasize the presence of divine will, such as St. Augustine (354 - 430) in his City of God in which he maintained that God's purpose is revealed in the unfolding of historical events. Beginning with the Old Testament and up to his own time, he traced the working of divine providence.

Some others have minimized the role of providence while exalting the role of the individual in the historical process. The latter was the case of Thomas Carlyle (1795 -1881) who considered that "the decisive and constructive forces in history are its great men and heroes."

Some schools discounted this generalization by emphasizing the impact of economic and other impersonal forces (for instance, environment, economic product etc.). The best example of these schools is the Marxist school which emphasizes the primacy of economic factors in the historical change. Some philosophers see history as progressive. For example, Plato, Herder, Hegel, and many other European thinkers tried in different ways to combine the Judeo-Christian views of time and history as progress in a straight line with the classical notion of historical cycles. ${ }^{4}$

Cyclical views, too, have frequently been maintained, both in antiquity and later. Vico (1668 - 1744), who is regarded by the Renaissance scholars as the pioneer of new science, took this sort of line, as did Toynbee, who tended to apply the empirical method to history, so far as he holds that civilization, even though it does not exactly have a fixed life span, nevertheless exhibits a common pattern of development and decay. ${ }^{5}$

On the other hand, the answers of those schools also vary regarding the units to be adopted to analyze and write history. Although the products of historical scholarship have become increasingly sophisticated and numerous, the problem of how to write world history and which unit of analysis is the most acceptable have remained unresolved. The need to find a solution, however, has grown increasingly throughout history with each of the many steps taken toward a global world history.

Consequently, in the absence of a generally accepted conceptual scheme which could provide the framework of unity, those who have attempted to write world

\footnotetext{
${ }^{3}$ Robert M Hutchins and Mortimer J. Adler, Gateway to the Great Books (Chicago: Encyclopedia Britannica, Inc, 1963), 6/ 108-109.

${ }^{4}$ William McNeill, The Expansion of The West: A History of The Human Community (Chicago: University of Chicago Press, 1963)

${ }^{5}$ Atkinson, Knowledge and Explanation in History, 210.
}

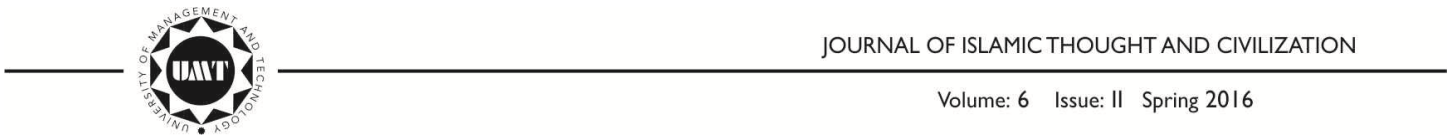


history have so far used three approaches. They used the model of series (sequence) of cultures or civilizations in which all cultures (civilizations) are subject to the same developmental pattern; the progress model; and the simple side-by-side histories of mankind's diverse peoples. ${ }^{6}$

As a matter of fact, the second and the third approaches had been dominant since the early beginnings of historiography. For the second approach, the works of Plato, St. Augustine and the early Christian historians can be mentioned. In addition, the Hegelians and Marxists, who considered history to be either linear retrogressive or linear progressive, belong to the same model. As for the third approach, it is an ancient approach to historiography, yet it is still supported by historians who focus on national and regional as well as racial and ethnic histories.

The most developed approach is the first one, which is based on the sequence model. If compared with the other two approaches, it is an attempt to break new ground in writing world history and finding the reason d'être for the course of history. It has emerged as a result of the efforts of the great scholars of civilizations, such as; Ibn Khaldun, Vico, Spengler, Toynbee, Elias, Braudel and others.

Ibn-e-Khaldun, for example, developed his cyclical view of history through his study of the history of various dynasties in the Muslim world, Europe and Asia both during and before his time. His concern about understanding the mechanisms of the rise and fall of states and dynasties led him, first, to detect in the history of those states and dynasties, a pattern of conquest from the desert followed by the corruption of the rulers as a result of luxury. After three generations, corruption prepared the way for a fresh conquest from the desert, to begin the cycle anew. Second, from his society's cases, Ibn-e-Khaldun developed his theory of cycles which considers the cycle of rise and fall as the pattern of historical change at the level of states and dynasties. ${ }^{7}$

Three centuries after Ibn-e-Khaldun, Vico in his The New Science attempted to present a cyclical theory of history of all nations. He sees history as a series of stages. Influenced by the Platonic ideal state, he believes real history is the "ideal, eternal history" which has three stages: the age of the Gods, to which the earliest institutions, religion, the family, and burial, belong; the "age of the heroes," in which heads of families united against the class of serfs; and the "age of men," in which the plebs finally established their human rights and the legal principle of equity. But the assertion of private interests leads to a decay of public spirit and the consequent

${ }^{6}$ Ernest Breisach, Historiography (Chicago: The University of Chicago Press, 1983), 396; Michael Stanford, A Companion to The Study of History (Oxford \& Cambridge: Blackwell, 1994), 1821.

7،Abd al-Rahmān Ibn-e-Khaldun, The Muqaddima: An Introduction to History, Translated from Arabic by Franz Rosenthal (London: Routledge \& Kegan Paul, 1986)

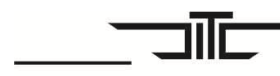

JOURNAL OF ISLAMIC THOUGHT AND CIVILIZATION 
breakdown of institutions, until finally there is a return to the barbarism of the state of nature, and the cycle began again on a higher level with the dawn of Christianity. ${ }^{8}$

The most important contribution of Vico to the study of history is his attempt to discover the general pattern of world history. Therefore, he asserted the existence of certain methodological rules to study historical change.

He held the view that certain periods of history had a general character which reappeared in other periods, so two different periods may have the same general character and it is possible to argue analogically from one to the other.

Moreover, he was of the view that those periods tended to recur in the same order. The age of gods is followed by the age of heroes which, in turn, is followed by the age of men. This is then followed by a decline into new barbarism and the age of gods. In other words, Vico put his cycle in the following way: first, the guiding principle of history is brute strength; then valiant or heroic strength; then valiant justice; then brilliant originality; then constructive reflection; and lastly a kind of wastrel. Additionally, this cyclical movement is not a mere rotation of history through a cycle of fixed phases; it is not a circle but a spiral. ${ }^{9}$

Therefore, one may agree that Vico, on the one hand, is a progressive, and a cyclical thinker, whereas actually he is not because he sees the cyclical movement not in circular form but in spiral form.

Spengler, as a matter of fact, presented world history as the story of "high" cultures (civilizations), of which so far there have been eight: Indian, Babylonian, Chinese, Egyptian, Islamic, Mexican, Classical, and Western. Based on his view that civilizations or cultures are an organic entities with a life cycle of a determined length and with no purpose beyond its unfolding, he saw that high cultures were those among the many cultures that, because of their special dynamics, brought forth outstanding achievements. After their creative careers had ended, they remained in a static state. ${ }^{10}$ To explain the rise and fall of civilizations, he used terms like; souls of cultures, uniform cultural life spans, and organisist parallels. Spengler suggested the "culture" as a preferred term for civilization in the German tradition. ${ }^{11}$

Toynbee, the English historian and the philosopher of civilization, for his part, viewed world history as a sequence of civilizations. For Toynbee, the intelligible units of historical study are not nations or periods but civilizations. ${ }^{12} \mathrm{He}$ also considered

\footnotetext{
${ }^{8}$ Muhammad Miraj, "Ibn-e-Khaldun and Vico: A Comparative Study," in Islamic Studies (19) (1980): 199- 205.

${ }^{9}$ Collingwood, The Idea of History, 67-68.

${ }^{10}$ Oswald Spengler, The Decline of The West, n.d.,1/ 3, 8, 31-37.

${ }^{11}$ Breisach, Historiography, 397.

${ }^{12}$ Arnold J. Toynbee, A Study of History, Abridgement by D. C. Somervell (Oxford: Oxford University Press, 1974), 1-6/ 3-11.
}

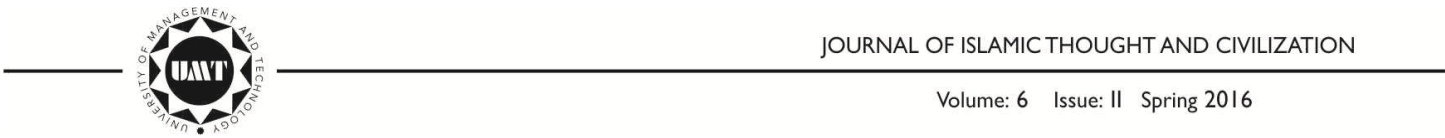


civilizations to be the result of a dialectic relationship between a challenge and response. Furthermore, he applied his theory to the civilizations of the world. So, he identified, analyzed, described and examined the rise and fall of more than twenty civilizations in the course of human history. ${ }^{13}$ Besides, he was of the opinion that the religions of the world provided the soil from which civilizations grew. ${ }^{14}$

As mentioned above, within the paradigm of philosophy of history, there are generally three schools which share the study of civilization and have generally distinctive paradigms within the broad paradigm of philosophy of history. They are the cyclical view paradigm; the progress view paradigm and the simple side-by-side histories of mankind's diverse people paradigm. ${ }^{15}$

While the side-by-side histories paradigm was a part of history in its "first order," the other two constructed the part of history in its "second order" and had a far-reaching influence and a greater impact on the study of civilization. They form the main views of the historical change of human conditions and the main schools which have approached the issue of civilization through their attempts to see patterns in historical change and conceptualize those patterns. ${ }^{16}$

In the following pages, this paper will critically review the contributions of the progressive view paradigm to the study of civilization. Moreover, the critical review will be based on Malek Bennabi's critical evaluation of the mentioned paradigm.

\section{Contributions of the Historical Progress School to the Study of Civilization}

The historical change regarding this school progresses from the primitive to the more developed and complicated. It was the nineteenth century which witnessed the advent of several theories within this school. ${ }^{17}$ Influenced by the growing and expanding project of enlightenment and modernity, the protagonists of the idea of progress saw history as a progressive process.

The reader should know that Hegel, Comte and Marx were the leading scholars of this school. ${ }^{18}$ Therefore, their contributions to the study of civilization have their presence in Bennabi's critical review of the dominant paradigms of the study of civilization, while he attempted to formulate and development his own approach.

\footnotetext{
${ }^{13}$ Patrick Gardiner, Theories of History (New York: The Free Press, 1959), 200; Ian P. McGreal, Great Thinkers of the Western World (Harper Collins Publishers, 1992), 515-517.

${ }^{14}$ Breisach, Historiography, 399.

${ }^{15}$ Breisach, Historiography, 396; Stanford, A Companion to The Study of History, 18-21.

${ }^{16}$ S. K. Sanderson, "Civilizational Approaches to World-Historical Change," Civilizations and World Systems, ed. S.K. Sanderson, (Walnut Creek: Altamira, 1995), 15.

${ }^{17}$ Hutchins, Gateway to The Great Books, 6/108.

${ }^{18}$ Arther Herman, The Idea of Decline in Western History (New York: The Free Press, 1996), 30.
}

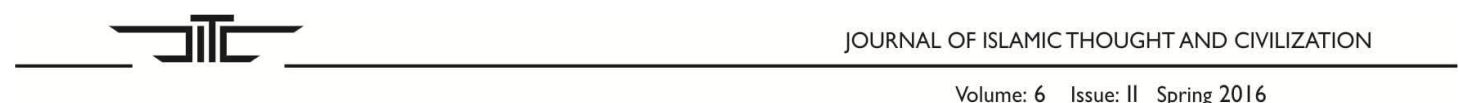


They believed in the progressive character of history, whether spiral (Hegel, Marx) or linear (Comte), although there was a difference in conceptualising the moving forces of history. They were the "prophets" of progress during the nineteenth century. ${ }^{19}$

For Hegel, world history was a battleground for ideas and spiritual forces; for Marx, it was a battleground for classes, technologies and economic forces. Hegel saw history progressing toward something like the Prussian Monarchy, whereas for Marx the goal was the classless society. ${ }^{20}$ Based on his idealistic worldview, Hegel considered the historical development of human civilization as being progressive and passing towards the last stage where the mind or the spirit leads to the absolute.

According to Hegel, there are three stages of the objective mind or spirit - the stage of abstract right; the stage of morality of conscience or subjective morality; and the stage of social morality or of the advent of the State. Furthermore, these three stages are more metaphysical than historical, contemplative rather than empirical. They form a rational process and are proved by speculative cognition. ${ }^{21}$ They do not refer essentially to the historical succession. Yet such dialectical progress is revealed or manifested in the consciousness of mankind in a particularly significant manner at certain moments of the historical evolution. ${ }^{22}$

For instance, abstract right was typically manifested at the time of the Roman Empire; the morality of conscience or subjective morality in the centuries of Catholicism, and still more in the eighteenth century Enlightenment. Whereas the third and final stage, the stage where all antinomies are resolved, appears in history when the German Protestant community takes political form and the State emerges as the objectivation of the divine. The latter, for Hegel, was manifested in the Prussian State. $^{23}$

Hegel's main contribution is his dialectical method. In the dialectical perspective, things which seem to be opposites are, in fact, only prior stages of a final synthesis. Therefore, history is the story of the progress of civilization and human freedom. For Hegel, humanity moves progressively toward its own idea of freedom, which is the "self-contained existence" of each individual. Progress, Hegel proclaimed, "is the boundless impulse of the world spirit - the goal of its irresistible urging."

\footnotetext{
${ }^{19}$ Ibid., 30.

${ }^{20}$ Hutchins, Gateway to the Great Books, 6/109.

${ }^{21}$ W. F. Hegel, The Philosophy of History, Trans by J. Sibree (New York: Dover Publications, Inc., 1956), 9.

${ }^{22}$ Ibid., 19.

${ }^{23}$ Ibid.,17-19.

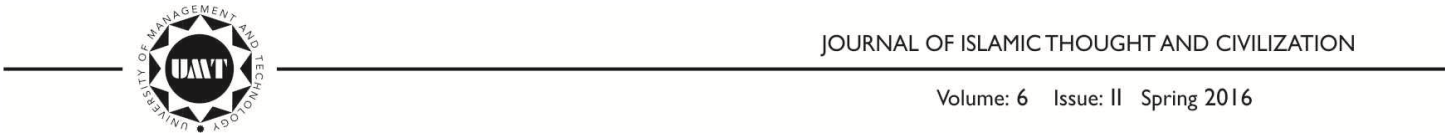


The first stage of civilization according to Hegel is the East "the Orient"; the civilizations of China, India, and the Middle East. At this stage humanity was in the childhood of its history. However, with the Greeks humanity reached its adolescence, where the idea of the freedom of the individual had been invented. And "therefore they were free, but they and the Romans likewise, knew only that some are free - not man as such."

According to Hegel, the Romans led in the "maturity" of mankind, when those 'same' free individuals and their slaves created a great material and political empire. It was succeeded by German or European world. The latter denotes the advent of modern civilization which represents the culmination of progress. Thus, Hegel proclaimed, Europe is absolutely the end of history "since the history of the world is nothing but the development of the idea of freedom." ${ }^{24}$ As the father of the idealist historical theory of the nation and historical progress, Hegel believed that the nation state worries would disappear. People become participants in a solid and stable "ethical social realm" created by the expansion of the state's powers and its professional and enlightened civil servants.

The other leading figure in the school of historical progress was Marx, who was interested in this dimension. Marx is one of the most influential personalities in the philosophy of history and the study of historical change. His approach was constructed on the same foundations as Hegel's: "the irresistible march of man's freedom." 25

While Hegel used the dialectic of the mind, Marx used the dialectic of economic means. Marx identified economics, rather than politics, as the key that unlocks man's progress through the law of class struggle. In other words, the irresistible economic forces governed men and determined trends in history. ${ }^{26}$ Furthermore, the advent of the Marxist approach was a declaration that history did not die, as Hegel proclaimed. Rather, there exists another stage after the stage of the nation state of Hegel.

Using Marxist terminology, a further stage lays beyond capitalism: socialism. In this latter, the society is classless and the Hegelian notion of state will be meaningless with the communist society where the desires of man are regulated on the basis of the Communist manifesto. ${ }^{27}$

\footnotetext{
${ }^{24}$ Ibid., 456.

${ }^{25}$ Herman, The Idea of Decline, 33.

${ }^{26} \mathrm{~T}$. Walter Wallbank, and Alastair M Taylor, and Nels M. Bailkey, Civilization Past and Present (Chicago: Scott, Fresman and Company, 1992), 5.

${ }^{27}$ Karl Marx, and Frederick Engels, "The Communist Manifesto," in Marx and Engels Collected Works, Vol. 6, 1845-1848 (New York: International Publishers, 1976), 4.
}

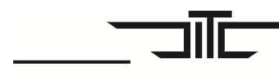

JOURNAL OF ISLAMIC THOUGHT AND CIVILIZATION 
The Marxists proclaimed that History would end with the advent of communism which is the practical part of the Marxist ideology. However, the Marxist explanation, in turn, made the same proclamation about the end of history. Accordingly, both made a deterministic and dead end to history. For both Hegel and Marx, history reaches an end point, beyond which it can go no further. ${ }^{28}$

Therefore, for Marx, it is the factor of economic forces that explains the historical change towards the supreme goal of the classless society. ${ }^{29}$ Thus, the needs and the technical means constitute, in the Marxist view, the axis of the forces of production. Similarly, they determine the social relationships of a given civilization and characterize the civilization in its moral and material aspects.

The other figure of the school of historical progress was the French philosopher August Comte. He was the intellectual heir of the supporter of the French revolution, Saint Simon (1760 - 1825) and both promised the humanity of the coming of the new age of human progress and rational understanding of the world, akin to a new religion. ${ }^{30}$ However, Comte was luckier to find a more prestigious position among the philosophers of history and sociologists. In his "positive philosophy" he proclaimed a redemptive message very similar to Hegel's. ${ }^{31}$

Much influenced by the evolution theory and the development of physical sciences, Comte attempted to apply the principles of physical sciences to the human conditions and historical change. During the nineteenth century, that notion was quite famous and the leading idea towards a new explanation of human history which tended to be a pioneering explanation in the era of "positive science" of society. ${ }^{32}$

He was influenced by the idea of progress, which played a pivotal role in nineteenth century Europe. It got spread in the European culture and supported by the idea of Darwin's theory of evolution and the idea of positivism of Comte himself.

In his notion of la loi des trois états, the law of the three stages or states, Comte presented another periodization of the various states in human history. For Comte, mankind and the human mind passed successively through the theological

\footnotetext{
${ }^{28}$ Herman, The Idea of Decline, 34.

${ }^{29}$ Hutchins, Gateway to the Great Books, 6/109.

${ }^{30}$ Herman, The Idea of Decline, 35; Irving M. Zeitlin, Ideology and the Development of Sociological Theory (Englewood Cliffs: Prentice Hall, 1994), 75.

${ }^{31}$ Auguste Comte, "Excerpts From 'From Metaphysics to Positivist Science," In Volker Meja and Nico Stehr, The Sociology of Knowledge, V, I (Massachusetts: Edward Elgar Publishing, Inc, 1999), 45; Mary Pickering, Auguste Comte: An Intellectual Biography (New York: Cambridge University Press, 1993), 1/188, 564, 669; Thomas Whittaker, Comte and Mill (Bristol: Thoennes Press,

${ }^{32}$ Scott Gordon, The History and Philosophy of Social Sciences (London: Routledge, 1991), 287; Pickering, Auguste Comte, 669.
} 1993), 15-16, 21.

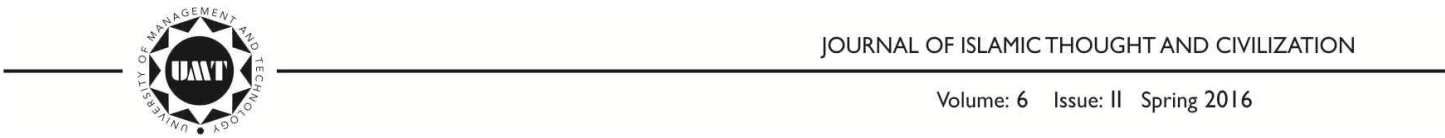


(supernatural), the metaphysical (abstract), and the positive (scientific) state. ${ }^{33}$ In the theological state, everything was explained by supernatural beings and wills. In the metaphysical state, abstract occult causes took the place of supernatural beings, and everything was referred to vital forces, substantial forms, etc. Finally, in the positive state, science is the unique rule - everything is to be understood in the light of sense verified science and "laws" or invariable relations between phenomena must replace both "wills" and"causes.", 34

From the historical point of view, the loi des trois états, the law of the three stages, is, even in the field of the knowledge of phenomena, a questionable and oversimplified generalization. But, it is pure fallacious reasoning to claim that theology and metaphysics are done away with because a thunderclap is not to be explained as an effect of some supernatural anger or of some occult qualities. Moreover, although Comte maintained that his law of three stages was the "abstract expression of general reality," he introduced no data that would have contested his theory. ${ }^{35}$

At this point, the reader may find that the main contribution of the school of historical progress is the explanation of historical movement; its stages and its causes. In this regard, it is important to see how Bennabi perceived and critically reviewed these contributions.

\section{Bennabi's Critical Review of the School of Historical Progress Approach}

In Bennabi's view, the interpretation of the movement of civilization has been the subject matter of various schools within the philosophy of history. However, the approaches of the philosophers of history or historians were too slow in developing a systematic and comprehensive approach to analyze historical change.

$\mathrm{He}$ asserted that the majority of the historians, starting from the Greek historian Thucydides (460 BC), until the French historian, Guizot (1787 - 1874) directed their attention towards assembling historical events, instead of developing a framework for providing a rational interpretation of these events.

With the coming of Guizot, the science of history begins, thanks to the enlightenment era, to provide a kind of scientific interpretation. However, even with

\footnotetext{
${ }^{33}$ Comte, From Metaphysics to Positivist Science; Whittaker, Comte and Mill, 15-16; Francis A Braham, John Henry Morgan, Sociological Thought From Comte to Sorokin (Madras: MacMillan India Limitted, 1985), 7-8.

${ }^{34}$ Robert C. Scharff, Comte after Positivism (Cambridge: Cambridge University Press, 1995), 74, 77- 91; Christopher G. A. Bryant, Positivism in Social Theory and Research (London: MacMillan Publishers Ltd, 1985), 28.

${ }^{35}$ Pickering, Auguste Comte, 669.
}

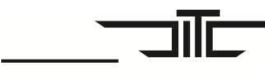

JOURNAL OF ISLAMIC THOUGHT AND CIVILIZATION 
Guizot, there was a certain Cartesian reservation which prevented him from forming a thorough and a systematic method. ${ }^{36}$

It was Bennabi's view also, that the eighteenth and nineteenth centuries were the centuries that witnessed various approaches to the interpretation of the historical movement of a civilization. In this period, many historians and philosophers had studied the causes that govern the historical movement and produced different interpretations of the course of history. ${ }^{37}$

It is this point, i.e., the explanation of the historical movement which aroused Bennabi's eagerness to undertake a critical review of the contributions of many philosophers of history. However, in his evaluation of the various interpretations of the historical movement, he made a special examination of the contributions of Hegel, Marx, and Comte. ${ }^{38}$

He considered Hegel's view as a reflection of the nineteenth century's political imagination on the role of state. Moreover, he did not comprehensively review Hegel's contribution. Rather, he reviewed the idea of contradiction which formulates, in Hegel's view, the motivating force that creates the historical movement and could generate its causes. ${ }^{39}$ In this regard, Bennabi acknowledged Hegel's emphasis on the importance of the realm of ideas in history.

Furthermore, Hegel ascribed every social change to the principle of contradiction between thesis and antithesis. Therefore, when the conflicting forces enter into interaction they generate an outcome of necessary infusion or synthesis. Those three phases govern every historical movement and constitute the process of social change. ${ }^{40}$

When Bennabi came to review Marx's contribution, he observed a link between Marx and Hegel. He considered that there was a link between the Hegelian notion of contradiction or the dialectic and the Marxist approach which conceives that the contradictory causes, which generate the social changes, are economic in nature. ${ }^{41}$ However, instead of the ideas based on contradiction of Hegel, Marx's explanation of historical change is based on the materialist understanding of history. He considers the progress towards a better society as the result of the economic contradiction. ${ }^{42}$

\footnotetext{
${ }^{36}$ Malek Bennabi, Shurūt al-Nahzah (The Conditions of the Renaissance) (Damascus: Dār alFikr, 1981), 62.

${ }^{37}$ Ibid., 62.

${ }^{38}$ Malek Bennabi, On the Origins of Human Society, trans. al-Mesawi, T Mohamed (Kuala Lumpur: The Open Press, 1998), 19.

${ }^{39}$ Malek Bennabi, Mīlād Mujtama (Birth of Society) (Damascus: Dār al-Fikr, 1986), 18.

${ }^{40}$ Ibid., 21.

${ }^{41}$ Ibid., 18

${ }^{42}$ Ibid., 18

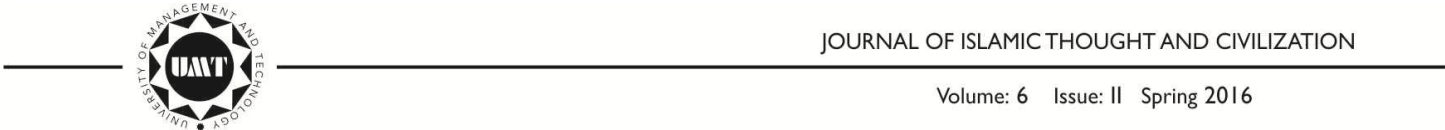


Therefore, Marxism's focus on the material aspect of civilization has led the Marxists to give primacy to the economic dimension over other dimensions. Thus, their interpretation is more "economistic." Accordingly, the historical change in this Marxian paradigm is based on the struggle of the classes. The class struggle between the proletariat and the bourgeoisie is the hallmark of the civilizing process. Therefore, the historical movement of civilization is a mere result of that dialectic class struggle.

In other words, Marx and his school were of the opinion that every historical movement that causes the birth of a civilization exists only as a result of the material necessities and the needs of man. This view, according to Bennabi, is too narrow and limited to some situations in Europe in the Victorian age. ${ }^{43}$

Although Marx's approach was one of the pioneering efforts to explain the social events within the framework of the phenomenon of civilization, it was too limited. ${ }^{44}$ Although, Marx and his heirs presented their approach in universal terms to reveal its generality and applicability to a wide range of human societies, they could not liberate their analysis from the spirit of Eurocentricism of the nineteenth century. ${ }^{45}$

The Marxist emphasis on the human needs and the technical means as the two poles of the modes of production, and the determinants of the type of social relationships of any civilization, and the determinants of the essence of the civilization per se morally and materially led Bennabi to assert that this approach does not explain the fundamental question that arises during the destruction or breakdown of social relationships and the disintegration of civilizations where there was no change in the nature of human needs or the means of production.

For instance, it does not explain the disintegration and decline of the civilizations of the Americas before the era of Columbus and the Roman civilization which did not disappear because of the poverty of human needs and technical means. Thus, we find an interruption in the Marxist interpretation and explanation of historical events caused by overindulgence in the methodology. That methodology starts from a materialistic predestination, i.e., it starts from an unconscious mechanical process in planning civilization. ${ }^{46}$

It, thus, appears that the Marxian school, with its approach, conceptualised man as a machine or unwilling being, and categorizes man, as a one dimensional being who exists bodily more than morally. Accordingly, Bennabi remarked that,:the Marxist thought also neglects the essential notion of cycle by its assertion that: the social and historical process move from the era of primitive animality to the era of

\footnotetext{
${ }^{43}$ Bennabi, On the Origins of Human Society, 20.

${ }^{44}$ Bennabi, Shurūt al-Nahzah, 63.

${ }^{45}$ Ibid., 63.

${ }^{46}$ Ibid., 63.
}

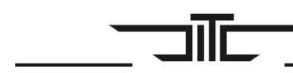

JOURNAL OF ISLAMIC THOUGHT AND CIVILIZATION 
abundance, consciousness and liberty, although the finalism implied in this perspective is contradicted by the very principle of the dialectic. ${ }^{47}$

Consequently, the Marxist interpretation of history as an old method was limited by the historical circumstances of nineteenth century Europe. ${ }^{48}$ Thus, it was overarched, during the twentieth century, by the advent of new approaches to the explanation of the genesis of civilization which opened the gates to other factors beyond the Marxist factors of human needs and technical means. ${ }^{49}$

In his opinion, Bennabi considered that the theory of human needs formulated by Marx is incapable of explaining the dynamics of a birth of a civilization. He argued that Marxists use a political periphrasis through their emphasis on the "class consciousness" of such a class. Thus, they ascribe a political character to the problem of civilization. However, he contends, the idea of human needs recalls the individualistic instinct of humans and involves competition and conflict. Therefore, every individual works for his own sake driven by biological rules. ${ }^{50}$

In other words, class-consciousness and the idea of human needs and material necessities do not lead to cooperation and integration. Rather, they lead to more conflict and competitiveness among the members of the society or community, which make it more difficult to unite the members of society towards a finality of their historical existence.

Historically speaking, Bennabi argued; if we apply to the Marxist approach its own rules of economic factors, the limits of its explanation on the economic map of the world will clearly be revealed to us as follows. Looking at the Marxist movement as an economic phenomenon will lead us to the conclusion that it actually corresponds to an economic zone representing the levels achieved by Japan, on the one hand, and England on the other. ${ }^{51}$

In this regard, Bennabi asserted the narrowness of the Marxist approach. He said,

We can ascertain that, unless the contrary is proven, the expansion of the Communist doctrine is confined to the economic frontiers which correspond to certain geographical boundaries and that, beyond these limits; the Marxist thought has failed to meet the conditions favorable for its adaptation. Therefore, it cannot

\footnotetext{
${ }^{47}$ Malek Bennabi, Islam in History and Society, Trans by Asma Rashid (Islamabad: Islamic Research Institute, 1988), 8.

${ }^{48}$ Bennabi, Mīlād Mujtama, 22.

${ }^{49}$ Bennabi, Shurūt al-Nahzah, 63.

${ }^{50}$ Ibid., 72.

${ }^{51}$ Bennabi, Mīlād Mujtama, 22.
}

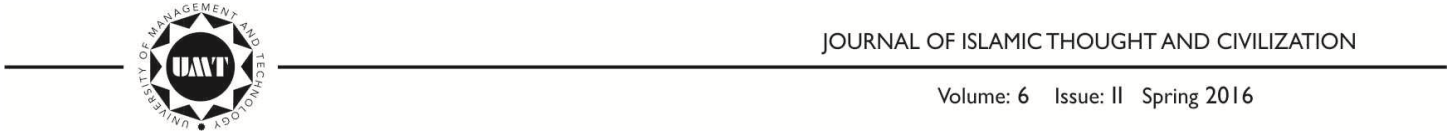


provide us with a reasonable interpretation that can be soundly applied to the areas where it has not spread. ${ }^{52}$

In his discussion of the stages of civilization, Bennabi saw that the notion of states or stages used by Hegel and Marx as well as their ideas about the motivating force of history do not explain the historical development of human civilization in general. It may explain certain histories, such as European history until the age of Hegel or Marx, but that notion, in its Hegelian and Marxist version, is biased and limited. It cannot be generalized to, and applied on human civilization in general. Furthermore, it provides an end to the development of human history and gives it a dead end. For instance, neither approach explains the genesis of Muslim civilization or its course in history. ${ }^{53}$

As for Comte, Bennabi acknowledged his contributions to the study of civilization. He considered him as the initiator of modern sociology after the long sleep since the time of Ibn-e-Khaldun who was the father of sociology ten centuries before Comte. ${ }^{54}$ However, the researcher would like to mention that although Bennabi acknowledged Comte's contributions, he was very critical of his positivistic vision of history. He was aware of an essential paradigm of positivism and Comte's law of the three states.

For Bennabi, it was, indeed, quite an interesting false generalization; it was possible to find inductively some indications for such a construction, on the one hand. On the other hand, any inductive result was understood and conceptualized in the light of an erroneous philosophy, namely, the positivist philosophy, for which everything is relative, here is the only absolute principle, and there is no other knowledge than the knowledge of phenomena and the interpretation of senseexperience. $^{55}$

Thus, Bennabi had his reservations about the positivist point of view which considers that the mathematical and physico-mathematical sciences, and all the different sciences of phenomena, constitute the only function of truth and real knowledge in human thought, and that, therefore, religion, mystical experience, metaphysics, and poetry are, in the civilized mind, an inheritance from the primitive and pre-logical mentality. ${ }^{56}$

${ }^{52}$ Bennabi, On the Origins of Human Society, 20.

${ }^{53}$ Bennabi, Shurūt al-Nahzah, 65.

${ }^{54}$ Malek Bennabi, Mushkilat al-Thaqāfah (The Problems of a Culture) (Damascus: Dār alFikr, 1984), 27.

${ }^{55}$ Malek Bennabi, The Problem of Ideas in The Muslim World, Trans by Mohamed T. Mesawi (Petaling Jaya: Budaya Ilmu Sdn. Bhd, 1994), 9.

${ }^{56}$ Bennabi, Mushkilat al-Thaqāfah.

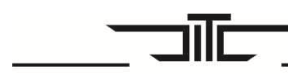

JOURNAL OF ISLAMIC THOUGHT AND CIVILIZATION 
In fact, what Bennabi criticised Comte about has been reflected by some writers who see that Comte's attitude towards various sciences is a major tenet of the positivists' philosophy of history. ${ }^{57}$

\section{Conclusion}

To sum up Bennabi's critical review of the School of Historical Progress, the reader may find that Bennabi criticized this school in many ways. He criticized the school of historical progress, because in his view, it is more theoretical than historical. On the other hand, it is based on Euro-centric worldviews that see the history of modern Europe as the culmination of the progress of human history without any critical analysis of the various civilizational experiences. Furthermore, they present approaches focusing on some variables of historical change while neglecting the complexity of a civilization as a multivariate phenomenon.

In fact, Bennabi acknowledged the care of the Hegelians about the role of ideas in changing history, and the Marxist praise of dialectical analysis. However, he argued that this school was not related to the nature of civilization. Consequently, he criticized this school in terms of the limitations in its method, concepts, and perspectives.

From another perspective, the researcher would say that Bennabi was aware of the general approach of this school regarding its focus on the universal process of civilization, at least at its theoretical level; the consideration of the general pattern of historical change; the search for a motivating force behind the movement of history; and the use of highly abstract concepts which denote the intention and awareness of the various figures of this school about the metaphysical aspect of civilization.

However, as Bennabi himself emphasized, it was his opinion about the importance of universal connection which led him to read and critically review the contributions of various philosophers of history, including, the protagonists of the school of historical progress. Thus, he came across those various approaches and conceptions which helped him to understand and uncover the universal framework of civilization $^{58}$ and, hence, to build up his interdisciplinary approach. ${ }^{59}$

${ }^{57}$ Irving M. Zeitlin, Ideology and the Development of Sociological Theory (Englewood Cliffs: Prentice Hall, 1994), 81-89.

${ }^{58}$ Malek Bennabi, Qadāyā Kubrā (Grand Matters) (Damascus: Dār al-Fikr, 1991), 7.

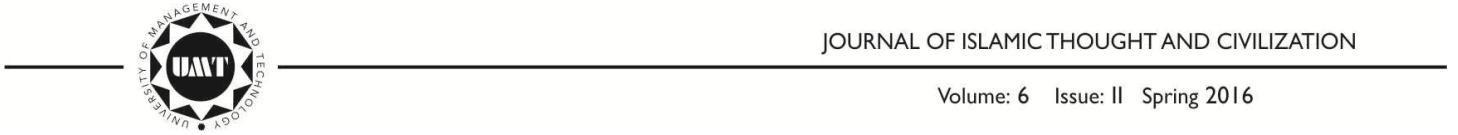




\section{BIBLIOGRAPHY}

Atkinson, R. F. Knowledge and Explanation in History: An Introduction to The Philosophy of History. Ithaca: Cornell University Press, 1978

Bennabi, Malek. Shurūt al-Nahzah (The Conditions of the Renaissance). Damascus: Dār al-Fikr, 1981.

-. Islam in History and Society. Trans by: Asma Rashid. Islamabad: Islamic Research Institute, 1988.

—. Mīlād Mujtama (Birth of Society). Damascus: Dār al-Fikr, 1986.

—. Mushkilat al-Thaqāfah (The Problem of Culture). Damascus: Dār al-Fikr, 1984.

-. On the Origins of Human Society. Translated by al-Mesawi, Mohamed T. Kuala Lumpur: The Open Press, 1998.

—. Qadāyā Kubrā (Grand Matters). Damascus: Dār al-Fikr, 1991.

- The Problem of Ideas in the Muslim World. Translated by Mohamed T. Mesawi. Petaling Jaya: Budaya Ilmu Sdn. Bhd, 1994.

Braham, Francis A and Morgan, John Henry. Sociological Thought From Comte to Sorokin. Madras: MacMillan India Limitted, 1985.

Breisach, Ernest. Historiography. Chicago: The University of Chicago Press, 1983.

Bryant, Christopher. G. A. Positivism in Social Theory and Research. London: MacMillan Publishers Ltd, 1985.

Collingwood R. G. The Idea of History. Oxford: Oxford University Press, 1993.

Comte, Auguste. Excerpts From "From Metaphysics to Positivist Science." In Volker Meja and Nico Stehr, The Sociology of Knowledge, V, I. Massachusetts: Edward Elgar Publishing, Inc., 1999.

Gardiner, Patrick. Theories of History. New York: The Free Press, 1959.

Gordon, Scott. The History and Philosophy of Social Sciences. London: Routledge, 1991.

Hegel, W. F. The Philosophy of History. Translated by J. Sibree. New York: Dover Publications, Inc., 1956.

Herman, Arther. The Idea of Decline in Western History. New York: The Free Press, 1996.

Hutchins, Robert M and Adler, Mortimer J. Gateway to the Great Books. Chicago: Encyclopaedia Britannica, Inc., 1963.

Ibn-e-Khaldun, 'Abd al-Rahmān. The Muqaddima: An Introduction to History. Translated from Arabic by Franz Rosenthal. London: Routledge \& Kegan Paul, 1986.

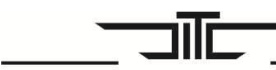

JOURNAL OF ISLAMIC THOUGHT AND CIVILIZATION 
Marx, Karl and Engels, Frederick. "The Communist Manifesto" In Marx and Engels Collected Works, Vol. 6, 1845-1848. New York: International Publishers, 1976.

McGreal, Ian P. Great Thinkers of the Western World. Harper Collins Publishers, 1992.

McNeill, William. The Expansion of the West: A History of the Human community. Chicago: University of Chicago Press, 1963.

Miraj, Muhammad. "Ibn-e-Khaldun and Vico: A Comparative Study." Islamic Studies (19) (1980): 199- 205.

Pickering, Mary. Auguste Comte: An Intellectual Biography. New York: Cambridge University Press, 1993.

Sanderson, S. K. "Civilizational Approaches to World-Historical Change." Civilizations and World Systems, ed. Sanderson, S. K. Walnut Creek: Altamira, 1995.

Scharff, Robert C. Comte After Positivism. Cambridge: Cambridge University Press, 1995.

Siddiqui, Abdul Hameed. A Philosophical Interpretation of History. Lahore: Kazi Publications, 1979.

Stanford, Micheal. A Companion tothe Study of History. Oxford \& Cambridge: Blackwell, 1994.

Toynbee, J. Arnold. A Study of History. Abridgement by: D. C. Somervell. Oxford: Oxford University Press, 1974, pp. 1-6/ 3-11.

Wallbank, T. Walter and Taylor, Alastair M and Bailkey, Nels M. Civilization Past and Present. Chicago: Scott, Fresman and Company, 1992.

Whittaker, Thomas. Comte and Mill. Bristol: Thoennes Press, 1993.

Zeitlin, Irving M. Ideology and the Development of Sociological Theory. Englewood Cliffs: Prentice Hall, 1994.

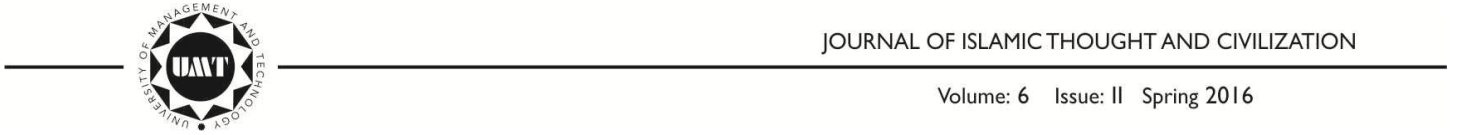

